\title{
The Role of Village Government in Cleaning Public Services at Petisah, Medan, Indonesia
}

\author{
Hadi Wahyudi Harahap', Humaizi², Abdul Kadir ${ }^{3}$ \\ ${ }^{1}$ Postgraduate Student at University of North Sumatera (USU), Indonesia \\ ${ }^{2,3}$ Lecturer at University of North Sumatera (USU), Indonesia \\ ahmedalbukhary@yahoo.com
}

\begin{abstract}
This study aims at describing and summarizing various conditions, various situations, or various phenomena of social reality that exist in life of society which are objects in this research and try to attract that reality to the surface so that it can be seen how social reality actually exists and is happening in life of society. This research was conducted in the Petisah Tengah Village, Medan Petisah village, Medan, North Sumatra Province. The researcher chose this village as the research location because of the diverse plurality of the people and the high level of socio-political dynamics because in this village there was the Medan Mayor's Office, as well as some government offices and Regional House of Representatives (DPRD) in Medan. This study used descriptive qualitative method. The type of research used by researchers in this study is a qualitative approach with descriptive studies. Qualitative research is a research procedure that produces description data in the form of words (both written and oral). This qualitative research method was chosen because it can present directly the nature of the relationship between researchers and respondents and is more sensitive and can adjust to the patterns of value faced. Data collection is done by observation and interview. The results of the study are more emphasized in giving an objective description of the actual state of the object under investigation, using a qualitative approach, the researcher will obtain more in-depth information or data.
\end{abstract}

Keywords: social reality; north sumatra province; government; medan petisah village; life of society.

\section{Introduction}

Development planning in urban areas cannot be separated from the implementation of the village government which is the leading unit in providing services to the community and is a strategic milestone in the success of all development programs. Therefore efforts to strengthen and empower the government at the village level are steps in accelerating the realization of welfare for the community as a goal in the village development program. To accommodate the aspirations of the community that continues to grow and in the face of changes that occur both in the national and international environment, it is necessary to have a strong urban government and supported by a system and working mechanism that is professional in providing good service to the community. The village administration must be truly ready and able to manage every potential that exists in the community to be able to realize prosperity for the community. The village government must also be fast and responsive in paying attention to everything that the community needs. It is expected that the creation of a strong and independent urban village government that can meet the needs of the community in order to improve the welfare of the community, and can realize planned development programs effectively and efficiently. The concept of village government empowerment can be implemented through a program to improve the quality or capability of local government officials. This is very important considering that village or desa are the smallest unit of government in the governance of the Unitary State of the Republic of Indonesia and are directly related to the community. Thus it is expected that government officials, especially at the village level, can improve good and quality services to the community. 
The village as the center of the foremost public services is expected to provide excellent service to residents who take care of all the requirements related to population administration. All matters ranging from the arrangement of $\mathrm{KTP}, \mathrm{PBB}, \mathrm{IMB}$, to the affairs of marriage or divorce in this office. The lives of many people do require the recognition of government administration so that life and life in society become calmer because all matters have legal power. Seeing such an important task, the village has become the most expected part of its role in supporting community empowerment, from 21 sub-districts and 151 sub-districts in Medan, Medan Petisah Subdistrict is one of the most strategic areas and is in the core of the city. Six) village namely Central Petisah Sub-District, West Sei Putih, Sei Putih Tengah, Skip, Sei Putih Timur I and Sei Putih Timur II. In this sub-district there are Medan Mayor's Office, as well as several Medan Government Offices and Regional House of Representatives (DPRD) of Medan. With the central role of the village government structure as the spearhead of the country's development and as the direct implementer of each policy issued by the government structure above, the role of the head of the environment is an integral part of the village government structure that is important and practically covers all matters become the task of the village government.

The phenomenon that occurs in the Petisah Tengah Village in Medan Petisah District is the lack of public knowledge about administrative requirements, lack of employee ability to provide socialization to the community to the lack of personnel which causes excess workload of employees which results in slow completion of community requests.

\subsection{Public Service}

\section{Review of Literature}

In Sinambela (2010: 6), theoretically the purpose of public service is basically to satisfy the community. To be able to provide satisfactory services for service users, the provision of services must fulfill service principles based on the Decree of the Minister of Administrative Reform Number 63 of 2003 covering:

1. Transparent: Services that are open, easy and accessible to all parties who need and are provided adequately and easily understood.

2. Accountability: Services that can be accounted for in accordance with the provisions of the legislation.

3. Conditional: Services that are in accordance with the conditions and ability of the giver and recipient of the service by adhering to the principles of efficiency and effectiveness.

4. Participatory: Services that can encourage community participation in the implementation of public services by taking into account the aspirations, needs and expectations of the community.

5. Similarity of Rights: Services that do not discriminate are seen from any aspect, especially ethnicity, race, religion, class, social status and others.

6. Balance of Rights and Obligations: Services that consider aspects of justice between the giver and recipient of public services.

\subsection{Performance}

Performance in general can be understood the size of the contribution that the employee gives to the progress and development in the institution where he works. Performance is the whole element and integrated process in an organization, which contains the distinctiveness of each individual, the behavior of employees in the organization as a whole and the process of achieving certain goals. The performance of government agencies is a description of the level of achievement 
of targets or government agencies as an illustration of the vision, mission, and strategy of government agencies that identify the level of success and failure in the implementation of activities in accordance with the programs and policies set.

Performance in the administration of government is the main responsibility of a leader, where the leader helps employees to perform better. Performance assessment is done by telling employees what is expected to build a better understanding of each other. Assessment must recognize achievement, and make plans to improve employee performance. Thus, there is actually a close relationship between individual performance and institutional performance.

In other words, if the employee's performance is good, it is likely that the institution's performance will be good. A person's performance will be better if he has a better future. Salaries and expectations, are important aspects that motivate employees to be willing to carry out work activities with better performance. If a group of employees and superiors have good performance, it will have an impact on good employee performance.

In order to build effective and efficient quality of government performance, it takes time to think about how to achieve cooperative unity so as to increase public trust. For that, autonomy and freedom are needed in making decisions to allocate resources, making guidelines for services, budgets, goals, and performance targets that are clear and measurable.

\subsection{The Performance of Lurah in Improving Public Services}

Performance in general can be understood the size of the contribution that the employee gives to the progress and development in the institution where he works. Performance is the whole element and integrated process in an organization, which contains the distinctiveness of each individual, the behavior of employees in the organization as a whole and the process of achieving certain goals. The performance of government agencies is a description of the level of achievement of targets or government agencies as an illustration of the vision, mission, and strategy of government agencies that identify the level of success and failure in the implementation of activities in accordance with the programs and policies set.

Performance in the administration of government is the main responsibility of a leader, where the leader helps employees to perform better. Performance assessment is done by telling employees what is expected to build a better understanding of each other. Assessment must recognize achievement, and make plans to improve employee performance. Thus, there is actually a close relationship between individual performance and institutional performance.

The fact shows that in carrying out their duties and responsibilities the village government faces several obstacles. One of them is the low professional capability of the apparatus, so that the performance of the village government has not been able to run properly. The achievement of the objectives of the village government duties and responsibilities is only possible because the efforts of the officials in the village government are in line with Prawirosentono's (1999) opinion that "the achievement of the objectives of the institution / company is only possible because of the efforts of the organizations/organizations "

But it needs to be understood that performance is not just the result of work or work performance, but also covers how the work process takes place. Simanjuntak (2005: 98) which states that:

"Performance is the level of achievement of results for the implementation of certain tasks. Company performance is the level of achievement of results in order to realize the goals of the company. Performance management is the whole activities carried out to improve the 
performance of companies or organizations, including the performance of each individual and working group in the company."

In line with the opinion expressed by Simanjuntak, Dessler (2009: 78) argues that:

"The performance (work performance) of employees is the actual performance of employees compared to the expected performance of employees. Expected work performance is a standard achievement prepared as a reference so that it can see employee performance in accordance with its position compared to the standards made. In addition, it can also be seen the performance of the employee towards other employees. "

Based on some opinions about performance and work performance it can be concluded that the notion of performance and work performance contains the substance of achievement of work results by someone. Thus, performance and work performance are a reflection of the results achieved by a person or group of people. Individual performance with performance institutions (institutional performance) or corporate performance (corporate performance) have a close relationship. In other words, if the performance of employees (individual performance) is good, it is likely that corporate performance is also good.

\section{Research Methods}

\subsection{Research Sites}

This research was conducted in the Petisah Tengah Village, Medan Petisah District, Medan City, North Sumatra Province. The researcher chose this Village as the research location because of the diverse plurality of the people and the high level of socio-political dynamics because in this village there was the Medan Mayor's Office, as well as several Medan City Government Offices and Regional House of Representatives (DPRD) of Medan.

\subsection{Types of Research}

The type of research used by researchers in this study is a qualitative approach with descriptive studies. Qualitative research is a research procedure that produces description data in the form of words (both written and oral). This qualitative research method was chosen because it can present directly the nature of the relationship between researchers and respondents and is more sensitive and can adjust to the patterns of value faced (Moleong, 2000). Descriptive research deals with collecting data to provide an overview or affirmation of a concept or symptom, also answering questions related to the status of the subject of the study.

This study aims to describe, summarize various conditions, various situations, or various phenomena of social reality that exist in people's lives which are objects in this research and try to attract that reality to the surface so that it can be seen how social reality actually exists and is happening in life community (Bungin, 2007: 21). The results of the study are more emphasized in giving an objective description of the actual state of the object under investigation, using a qualitative approach, the researcher will obtain more in-depth information or data.

\subsection{Source of Data}

Primary data is data obtained in the field or in the research area. Primary data is unprocessed data or raw data in the form of interviews and this data is obtained through direct interview techniques. The primary data collection technique is the collection of data obtained through research activities directly to the location of the study to find data that is complete and related to the problem under study. The data collection techniques performed are: 
a. Observation is a method of data collection used to collect research data, where research data can be observed by researchers. In the sense that the data is collected through observations of researchers through sensory use (Bungin, 2001). In this study, researchers conducted direct observations to the Petisan Tengah Village.

b. In-depth interviews, namely the process of question and answer conducted directly and deeply aimed at informants at the research location with draft questions that have been prepared and adapted to the formulation of existing problems, and using guidelines or interview guidelines and interview tools such as tape recorders, small notes and others to obtain data and information about the Central Petisah Village.

Secondary data is data obtained through library studies by reading books, literature, journals, newspapers and various other information relating to the problem under study. This secondary data is intended as supporting data to complete the primary data. Secondary data collection in this study was carried out by library research and document recording, namely collecting various information from reference books, journals, magazines and the internet which were considered relevant to this research.

\subsection{Data collection technique}

In each research process, data collection aims to reveal facts about the subject under study. Therefore, in this study several methods are used as references to collect data, namely as follows:

The researcher collected data by direct and in-depth interviews. Where the researcher will ask several questions related to the focus of the problem in this thesis, namely:

1. How is the service performance of urban village employees in the community in the Petisah Tengah Sub-District, Medan Petisah?

In this case the lurah participates in providing services and giving instructions to the employees who are in the village to make things easier for the residents who want to deal with the Head of the Village Office and the village head directly to the field to find out what is happening in the area.

2. What are the supporting and inhibiting factors for the performance of village employees in serving the community in the Petisah Tengah Village, Medan Petisah Subdistrict?

In this case the supporting factors in improving service performance in the community are where the village head and village staff always coordinate and the village head goes directly to the community to find out what complaints from the community, while the inhibiting factor is where the community is awkward or lazy because the community has thought that if the head of the lurah office they deal with it will be complicated.

In this data collection technique in order to obtain data, the conversation is conducted by two parties, namely the interviewer (interviewer) who asks questions and the interviewee (interviewee) who provides answers to questions, with resource persons who are considered researchers are representatives representing the organization, religion, employment, economic conditions and gender. In addition to conducting interviews, researchers also carried out library study data collection techniques, namely a data collection technique based on reading materials related to research. By reading the literature sources that have to do with the problem of this research. Books, journals, articles , magazines, newspapers, opinions and other written information.

\subsection{Informant}

Informants are people who become sources of information in research. Informants are considered as people who master and understand data, information or facts from an object of 
research (Bungin, 2008). The selection of informants for researchers used a purposive sampling technique to determine the research subject. Purposive technique Sampling is used if in the selection of researcher informants using certain considerations. So the researcher determined several criteria for the informant (Idrus, 2009).

The sources of information to obtain data from this study are:
a. PetisahTengah Village Head
: 1 Person
b. Head of Middle Dispersal Environment
: 1 Person
c. Youth Figures in Petisah Tengah Village
: 1 Person
d. Community Leader of Petisah Tengah Village
: 3 People
e. Chairperson of PKK Petisah Tengah Village
: 1 Person
f. Ordinary Society
: 1 Person

\section{Discussion}

Bureaucratic performance can actually be seen through various dimensions, such as dimensions of accountability, responsibility and responsiveness, apparatus in providing services. Various literatures that discuss the performance of bureaucracy basically have substantial similarities, namely to see how far the level of achievement has been made by the service bureaucracy. Performance is a concept that is prepared and various indicators that vary greatly according to the focus and context of its use.

In order to make the hygiene program successful in the framework of urban village empowerment towards achieving a healthy and clean environment quality, the Petisah Tengah District, Medan Petisah Subdistrict has carried out various pro-active actions to succeed the environmental sanitation program. The efforts that have been carried out by the village are referring to the work indicators that were appealed to the instruction of the Mayor of Medan. In accordance with the appeal, the Petisah Tengah Village, Medan Petisah District has made various efforts and steps to create a clean and beautiful neighborhood.

The various steps taken by the Village are by conducting a socialization and direct approach to the community about the importance of hygiene and environmental health. In the socialization, the village gave various appeals to the community to maintain the cleanliness of the environment and invited the community to directly play a role and maintain the cleanliness of the environment by holding the village-based mutual assistance that was implemented every Saturday and Sunday in predetermined locations.

The condition of the level of cleanliness of the environment before the implementation of this program is very much different from the achievement of cleanliness that exists today. The current handling of cleanliness is more controlled and shows the face of the Village that seems clean and comfortable. This condition is a positive effect of the implementation of empowerment programs in the field of hygiene, where the existence of the program requires the responsibility of all parties, both the village and the community to collectively create cleanliness in all urban areas. This was supported by one of the informants from the Village, namely Mr Agha who said:

"To maintain the cleanliness of the surrounding environment, people usually dispose of garbage in its place and are assisted by an appeal from the village that with the transfer of authority to the District so that the Sub-district submits to the village that garbage is quoted by the garbage transport car at the appointed hour (20.00 WIB) . At this time the community has collected the garbage ". 
The above phenomenon shows that the existence of programs that deal directly with the community when carried out with awareness-raising approaches will bear positive fruit and can show good results towards the achievement of expected program results. This is in accordance with the narrative of Mr. Agha Novrian:

"The village has socialized the schedule of transporting waste to the community through the head of the environment so that the schedule that has been determined by the community has collected the trash and will be transported by a garbage carrier so that there is no pile of garbage around the environment".

The commitment and seriousness of the village in creating a clean and beautiful environment should not only be limited to enthusiasm but must be realized with real work and support from various important elements, especially regarding the support of operational facilities and infrastructure. In implementing this environmental hygiene operation, the Petisah Tengah Village, Medan Petisah Subdistrict was supported by the availability of supporting facilities and infrastructure. In technical matters the village has a variety of supporting facilities that are still of sufficient quality or are still in good condition, such as the availability of 1 typer which operates daily on major roads or major roads in each sub-district area.

In addition, for each village, as a temporary waste collection from household / community waste, a container is placed in the most strategic place. For the collection of garbage in alleys or housing that is far from the main road, there are 2 pieces of trash rickshaw and 5 units of trash cans. And to operationalize the work tools, the village has 7 staff / workforce personnel, 7 people from Melati, 2 people from the trash rickshaw and 5 people from the stroller. This is in accordance with the following public figures:

"The village has informed the public of the schedule for the installation of garbage cars so we residents always collect garbage in the shelter in the hour approaching the transportation ours so that the garbage pile is not too long in the reservoir. So our environmental conditions are also cleaner. "

The availability of supporting facilities and infrastructure as well as available operational personnel is certainly not going to be maximal in handling hygiene issues in the entire Petisah Tengah District, Medan Petisah District. Community awareness and participation is a key factor in creating cleanliness in this village. In this case the village is very active in inviting the public to jointly maintain environmental cleanliness starting from the cleanliness of their homes. Besides this, the village also held a "do not litter" campaign in strategic locations around the Petisah Tengah Village, Medan Petisah Subdistrict.

Medan Petisah Subdistrict, including being very successful in handling hygiene problems. This can be seen from the high willingness and awareness of the community to work together in implementing hygiene. In this case the community was involved in their participation through mutual cooperation which was held every week on Saturday and Sunday coordinated by each Head of Environment in the Petisah Tengah Village, Medan Petisah District. In the field of security, the community together supports the creation of security by maintaining the security of their respective environments by building security posts in their neighborhood. Community participation was also reflected in their enthusiasm in working together to do sidewalk painting and cleaning the road walls and also cleaning the waterways. 


\section{Conclusion}

Development planning in urban areas cannot be separated from the implementation of the village government which is the leading unit in providing services to the community and is a strategic milestone in the success of all development programs. Therefore efforts to strengthen and empower the government at the village level are steps in accelerating the realization of welfare for the community as a goal in the village development program. The commitment and seriousness of the village in creating a clean and beautiful environment should not only be limited to enthusiasm but must be realized with real work and support from various important elements, especially regarding the support of operational facilities and infrastructure. In implementing this environmental hygiene operation, the Petisah Tengah Village, Medan Petisah Subdistrict was supported by the availability of supporting facilities and infrastructure.

This study aims to describe, summarize various conditions, various situations, or various phenomena of social reality that exist in people's lives which are objects in this research and try to attract that reality to the surface so that it can be seen how social reality actually exists and is happening in life community (Bungin, 2007: 21). The results of the study are more emphasized in giving an objective description of the actual state of the object under investigation, using a qualitative approach, the researcher will obtain more in-depth information or data. This research was conducted in the Petisah Tengah Village, Medan Petisah District, Medan City, North Sumatra Province. The researcher chose this Village as the research location because of the diverse plurality of the people and the high level of socio-political dynamics because in this village there was the Medan Mayor's Office, as well as several Medan City Government Offices and Regional House of Representatives (DPRD) of Medan.

\section{References}

A, A, Anwar, Prabu, Mangkunegara. 2009. Manajemen Sumber Daya Manusia. Bandung : PT. Remaja Rosdakarya.

Abidin, Zainal. 2010. Analisis Pengaruh Keandalan dan Etos Kerja Terhadap Pelayanan Publik Pegawai Kantor Pelayanan Pajak Pratama Medan Kota. Medan : USU.

Agus, Dharma. 2001. Manajemen Supervisi. Jakarta : Raja Grafindo Persada.

As'ad, M. 2003. Psikologi Industri : Seri Sumber Daya Manusia, Yogyakarta : Liberty.

Bungin, Burhan. 2008. Analisis Data Penelitian Kualitatif. Jakarta: Raja Grafindo Persada.

Bungin, Burhan. 2009. Analisis Penelitian Data Kualitatif. Jakarta: Raja Grafindo

Levinso, Soekanto. 2009. Peranan, Edisi Baru. Jakarta : Rajawali Pers.

Lupiyoadi , Rambat. 2001. Manajemen Pemasaran Jasa. Jakarta : PT. Salemba Empat.

Moleong, Lexy J. 2007. Metodologi Penelitian Kualitatif, Penerbit PT Remaja Rosdakarya Offset, Bandung

Muhammad Idrus. 2007. Metode Penelitian Ilmu Sosial. Yogyakarta: Erlangga.

Parasuraman, dkk. 1998. Service quality : A multiple item scale for measuring consumer perception of service quality.

Prawirosentono, Suyadi. 1999. Kebijakan Kinerja Karyawan. Yogyakarta : BPFE.

Rasyid. Ryaas. 1997. Kajian Awal Birokrasi Pemerintahan Politik Orde Baru. Jakarta : PT Yarsif Watampone.

Ratminto dan Atik Septi Winarsih. 2005. Manajemen Pelayanan. Yogyakarta : Pustaka Belajar. 
Rivai, Veithzal. 2005. Manajemen Sumber Daya Manusia untuk Perusahaan, dari Teori ke Praktik. Jakarta : PT. Raja Grafindo Persada.

Robbins, Stephen P. 2006. Perilaku Organisasi.Edisi kesepuluh. Jakarta : PT. Indeks Kelompok Gramedia.

Ruky, Achmad, S. 2001. Manajemen Penggajian dan Pengupahan Untuk Karyawan Perusahaan Edisi Pertama. Jakarta : Gramedia Pustaka Utama.

Shadily, Hasan.1992. Sosiologi untuk masyarakat Indonesia. Jakarta : Rineka Cipta.

Sedarmayanti. 2011. Manajemen Sumber Daya Manusia, Reformasi Birokrasi dan Manajemen Pegawai Negeri Sipil (cetakan kelima). Bandung : PT Refika Aditama.

Simanjuntak, Payaman J. 2005. Manajemen dan Evaluasi Kinerja. Jakarta: FE UI.

Sinambela, L.P. 2010. Reformasi Pelayanan Publik;Teori,Kebijakan dan Implementasi, cetakan kelima. Jakarta : PT. Bumi Aksara.

Soedjono. 2005. Pengaruh Budaya Organisasi terhadap Kinerja Organisasi dan kepuasan Kerja Karyawan pada Terminal Penumpang Umum di Surabaya. Jurnal Manajemen dan kwirausahaan Vol. 7 No. 1. Surabaya : STIESIA.

Soerjono Soekanto. 2009. Peranan Sosiologi Suatu Pengantar, Edisi Baru. Jakarta : Rajawali Pers.

Wibowo. 2010. Manajemen Kinerja, Edisi Ketiga. Jakarta : PT. Raja Grafindo Prasada.

Undang-Undang Nomor 22 Tahun 1999 Tentang Pemerintahan Daerah

Undang-Undang Nomor 32 Tahun 2004 Tentang Pemerintahan Daerah

Undang-Undang Nomor 23 Tahun 2014 Tentang Pemerintahan Daerah

PP No. 73 Tahun 2005 tentang Pemerintahan Kelurahan

PP No. 41 Tahun 2007 tentang Organisasi Perangkat Daerah

PP No. 19 Tahun 2008 tentang Kecamatan

KEPMENPAN No. 63 Tahun 2003 tentang Pedoman Umum Penyelenggaraan Pelayanan Publik 